\author{
В.М. Петров ${ }^{1}$, А.А. Шалигін ${ }^{1}$, А.Ф. Кудрявцев ${ }^{1}$, Ю.Б. Ситник ${ }^{2}$, О.М. Марченко ${ }^{1}$, К.Ю. Сурков $^{2}$ \\ ${ }^{1}$ Харківський національний університет Повітряних Сил ім. І. Кожедуба, Харків \\ ${ }^{2}$ Льотна академія Наџіонального авіаційного університету, Кропивниџький
}

\title{
ФОРМИ ТА СПОСОБИ СПІЛЬНОГО ЗАСТОСУВАННЯ ПІЛОТОВАНОЇ ТА БЕЗПІЛОТНОЇ АВІАЦІЇ ПРИ ВЕДЕННІ БОЙОВИХ ДІЙ
}

\begin{abstract}
У статті розглянуті основи тактики спільного застосування пілотованих та безпілотних літальних апаратів при веденні бойових дій у складі зміманих різнорідних груп авіації. До основних положень тактики віднесені форми і способи бойового застосування, бойові порядки та завдання авіації, тактичні прийоми їх виконання, функціонування системи управління. Відповідно для спільного застосування змішаних різнорідних груп авіачії запропановані форми їх бойового застосування та узагальнений спосіб бойових дій, надане поняття змішаного бойового порядку, його кількісно-якісного складу та параметрам. Приведені часткові завдання різних груп тактичного призначення та літальних апаратів змішаного бойового порядку, варіанти тактичних прийомів подолання системи протиповітряної оборони та нанесення ударів. Запропанований напрям удосконалення існуючої системи управління авіації для можливості спільного застосування пілотованих та безпілотних літальних апаратів у різнорідних групах, який полягає в інтеграції системи управління $і$ зв'язку безпілотних авіаційних комплексів в існуючу автоматизовану систему управління авіацією $i$ протиповітряною обороною Збройних Сил Украйни із створенням єдиного інформаційного простору.
\end{abstract}

Ключові слова: ударна авіація, літальний апарат, авіаційний удар, бойовий порядок, тактичний прийом.

\section{Вступ}

Постановка проблеми. За поглядами військових експертів провідних країн світу до 2050 року всі завдання, що виконуються пілотованою авіацією, повинні бути покладені на безпілотну авіацію [1-6]. На перехідних етапах для виконання поставлених бойових завдань може бути задіяна як пілотована, так і безпілотна авіація, у тому числі в змішаних бойових порядках. Залежно від обстановки і поставлених завдань, та чи інша авіація повинна буде виконувати основну або допоміжну роль (в якості груп забезпечення). На даний час основна роль при веденні бойових дій відводиться пілотованій авіації. 3 розвитком та вдосконаленням безпілотних авіаційних комплексів (БпАК) будуть змінюватися погляди на пріоритети застосування пілотованої та безпілотної авіації, відповідно змінюватися тактика авіації, зокрема форми і способи бойового застосування, бойові порядки та завдання, відпрацьовуватися нові тактичні прийоми їх виконання, удосконалюватись система управління авіацією. В основу цих змін, вочевидь, буде покладено принцип використання переваг пілотованих або безпілотних літальних апаратів (БпЛА). Вже сьогодні назріла потреба розробки тактики спільного застосування пілотованих та БпЛА у складі змішаних різнорідних груп авіації (ЗРГА) [4-12].

Аналіз останніх досліджень і публікацій. Проблемам спільного застосування пілотованої i безпілотної авіації останнім часом приділяється велика увага як у збройних силах нашої країни, так і у провідних країнах світу. Результати досліджень відображаються в наукових публікаціях, військовотеоретичних роботах і різних посібниках [1-10].

У вказаних роботах досліджені питання створення міжвидової системи управління угрупуванням сил пілотованої і безпілотної авіації, способи спільних дій пілотованих і БпЛА $з$ метою підвищення ефективності бойових дій (за рахунок зменшення втрат пілотованої авіації і покращення точності нанесення ударів), приведені результати експериментальної апробації способу спільного застосування пілотованої авіації і розвідувально-ударних БпЛА малої дальності. В роботі [7] запропонований математичний апарат розв'язання проблеми формування у польоті спільного бойового порядку пілотованої та безпілотної авіації.

Області досліджень в цих роботах обмежені, не охоплюють спектр основ тактики спільного застосування пілотованих і БпЛА, зокрема форм їх бойового застосування і способів бойових дій. Тому актуальним стає саме цей напрям досліджень.

Мета статті. На основі існуючої тактики пілотованої авіації відпрацювати засади спільного застосування пілотованих та безпілотних літальних апаратів при веденні бойових дій у складі ЗРГА.

\section{Виклад основного матеріалу}

Основною формою бойового застосування ЗРГА, в складі яких можуть знаходитися БпАК різ- 
ного класу і призначення, будуть залишатись бойові дії (рис. 1). У бойових діях ЗРГА будуть виконувати поставлені перед ними бойові завдання складом виділених сил і засобів нанесенням авіаційних ударів, виконанням спеціальних бойових польотів i веденням протиповітряних (повітряних) боїв.

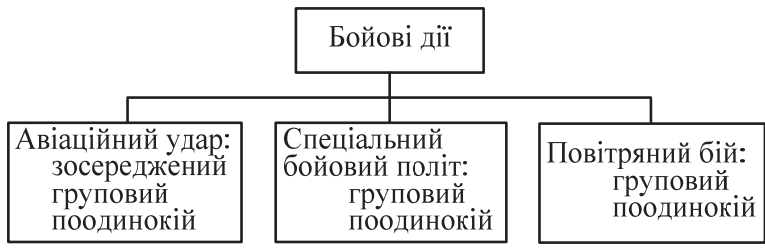

Рис. 1. Форми бойового застосування змішаних різнорідних груп авіації

Джерело: розроблено авторами.

Авіаційний удар в даному контексті розглядається як вогневий вплив на противника виділених сил зі складу ЗРГА для знищення його наземних (морських) об'єктів із застосуванням різних авіаційних засобів ураження (АЗУ). Він може бути зосередженим, груповим, одиночним і водночас різнорід- ним (в залежності від кількісно-якісного складу сил, що залучаються до нанесення удару).

При застосуванні ЗРГА особливу увагу слід приділяти порядку застосування сил і засобів при виконанні бойового завдання, тобто вибору способу бойових дій. Цей вибір буде залежати від прийнятих прийомів дій та різних чинників (рис. 2).

Виходячи 3 аналізу вказаних прийомів можливих дій і чинників, узагальнений спосіб спільних бойових дій ЗРГА при виконанні ударних бойових завдань можна сформулювати наступним чином: спільні бойові дії змішаних різнорідних груп пілотованої і безпілотної авіації різного класу і призначення при виконанні завдань ураження об'єктів противника шляхом одночасних (послідовних) ударів всім складом або частиною сил по заздалегідь заданим (знову виявленим в ході бойових дій) об'єктам противника у визначений час (за викликом 3 положення чергування на землі або в повітрі). Даний узагальнений спосіб буде відрізнятися від відомих способів попередніми (забезпечуючими) діями БпЛА [14-18].

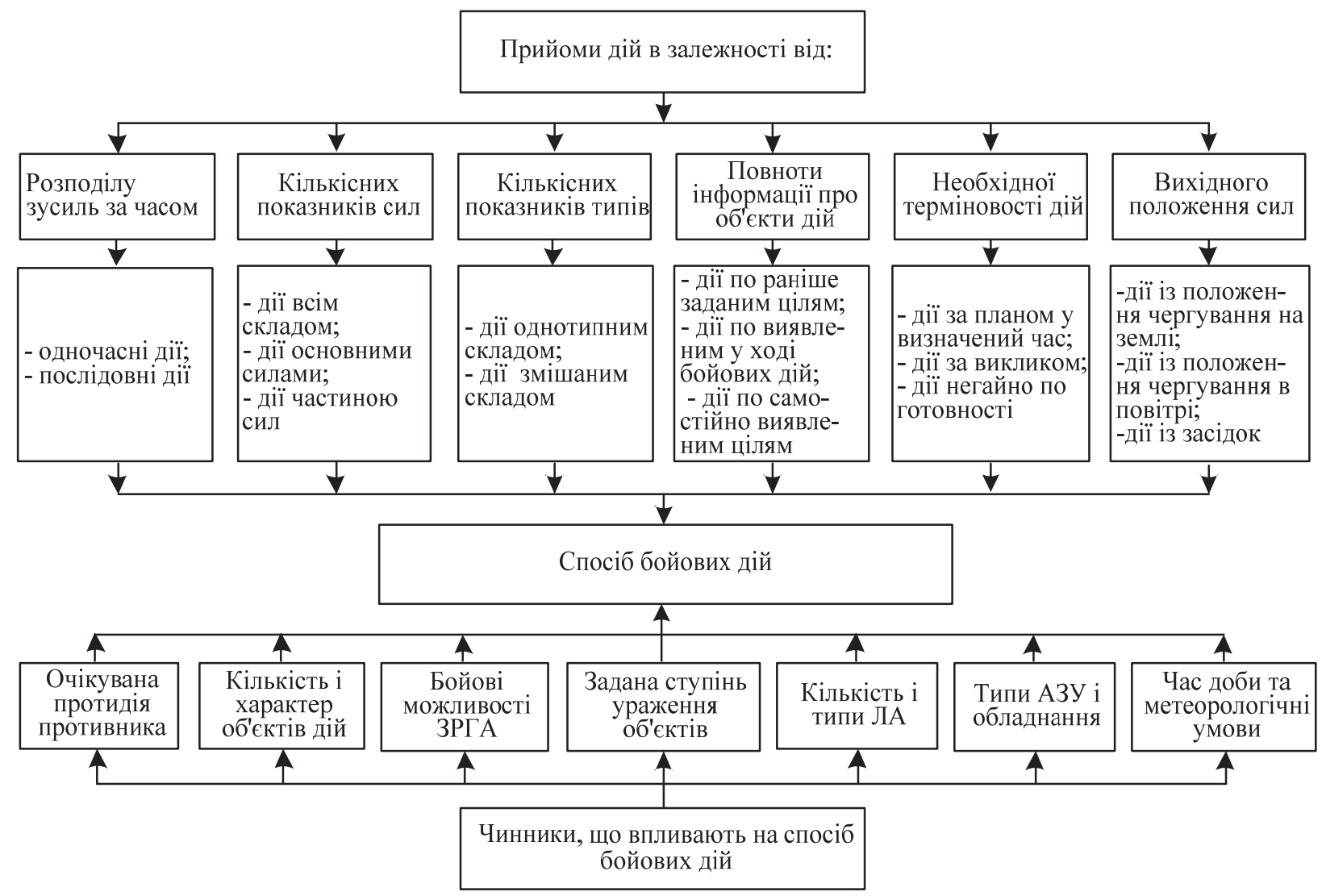

Рис. 2. Основні прийоми дій та чинники, що впливають на вибір способу бойових дій змішаних різнорідних груп авіації Джерело: розроблено авторами.

Для підрозділів (пілотованих і безпілотних ЛА) радіоелектронної боротьби, крім цього, існують способи їх бойового застосування а саме, із зон, 3 бойових порядків, з груп постановників перешкод, що діють за самостійним маршрутом.

При виконанні бойових завдань у складі ЗРГА ЛА повинні виконувати політ у загальному бойовому порядку, який включає групи різного тактичного 
призначення, кожна $з$ яких повинна виконувати своє часткове бойове завдання і використовувати свій спосіб ведення бойових дій. В існуючій тактиці авіації бойовий порядок трактується як взаємне розташування ЛА або груп тактичного призначення (ГТП) в повітрі для спільного виконання бойового польоту [16-18]. У змішаних бойових порядках його призначення може бути іншим - для спільного виконання бойового завдання. Ця різниця може з'являтися у випадках, коли льотно-тактичних характеристик (ЛТХ) різнорідних за своїм складом пілотованих i безпілотних ЛА не дозволять дати можливості виконання польоту в загальному бойовому порядку. Бойовий порядок ЗРГА може включати відомі ГТП [16-18]: основну (ударну, десантну, транспортну або іншу) групу, групи забезпечення і резерв. Основна група призначається для виконання головного бойового завдання. Групи забезпечення - для створення сприятливих умов основній групі. Варіант змішаного бойового порядку різнорідного авіаційного під- розділу, що має у своєму складі групи різного призначення, показаний на (рис. 3). ГТП, які виділяються для забезпечення, в одному бойовому польоті послідовно або паралельно можуть виконувати декілька завдань в різному поєднанні (наприклад, здійснювати дорозвідку і позначення цілі, дорозвідку та ураження засобів ППО, РЕБ, демонстративні діi) [10-13]. Кількісно-якісний склад і місце цих ГТП в бойовому порядку будуть визначатися в залежності від бойового завдання, умов її виконання, етапів польоту i тактичних прийомів подолання ППО та нанесення удару. Форми і види бойових порядків залишаться, можуть змінитися лише їх параметри (дистанції, інтервали і перевищення) 3 появою можливості їх приладового визначення та автоматизації утримання. Основним видом бойового порядку при діях у складі ЗРГА буде розосереджений, в ГТП - розімкнутий і рідше зімкнутий $[5 ; 20-$ 21].

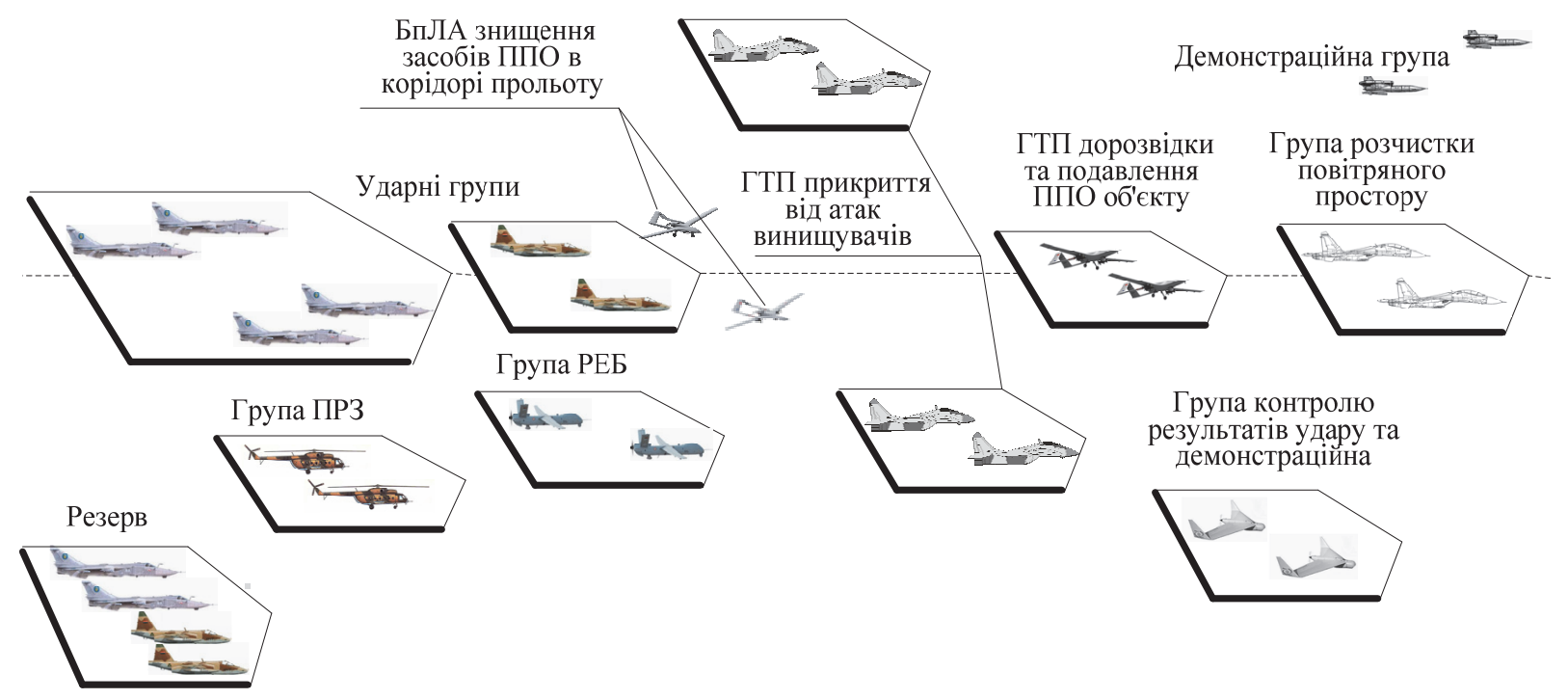

Рис. 3. Варіант бойового порядку змішаної різнорідної групи авіації Джерело: розроблено авторами.

Для успішного подолання ППО противника у складі ЗРГА необхідно виконувати об'єднаний загальним замислом комплекс заходів забезпечення (розвідку, вогневе і радіоелектронне подавлення засобів ППО, прикриття винищувачами), а в повітрі застосовувати відомі тактичні прийоми (обхід зон ураження; політ на вигідних режимах і в доцільних бойових порядках за раціональними маршрутами i профілями; маневрування проти засобів ППО) [5; 16-18].

На сьогоднішній день БпАК можна використовувати для виконання завдань розвідки, дорозвідки та подавлення (в тому числі вогневого) засобів ППО в коридорі прольоту і в районі цілі, ураження одиночних об'єктів, ретрансляції, демонстраційних дій. Розробка тактичних прийомів буде залежати, перш за все, від протидіючих сил і засобів противника, ЛТХ застосовуваних БпАК, створеної спільної системи управління. Дії всіх ГТП повинні плануватися за єдиним часовим графіком з прив'язкою до моменту (періоду) дій основної групи (наприклад, моменту часу “Ч”). Кожна ГТП свої часткові завдання повинна виконувати відповідно до того єдиного графіка, для цього призначаються зрівняльні (контрольні) рубежі (ЗР), на які повинен бути забезпечений точний вихід їх за місцем і часом. Ці рубежі повинні встановлюватися на найбільш відповідальних етапах (ділянках) польоту, наприклад ЗР № 1 рубіж закінчення побудови бойового порядку основної (ударної) групи, ЗР № 2 - лінія бойового зіткнення (ЛБ3), ЗР № 3 - рубіж нанесення удару (ціль). При плануванні бойових дій призначається час ви- 
ходу ведучого ударної групи на ці рубежі для координації дій інших ГТП за часом. Очевидно, що при цьому менш швидкісні ЛА повинні виконувати політ попереду основної (ударної) групи, щоб вона наздоганяла їх до моменту виконання дій забезпечення на різних етапах польоту. Варіант тактичних прийомів подолання ППО противника і нанесення удару ЗРГА наведений на рис. 4 [5; 14; 19-21].

На сьогоднішній день у ПС ЗС України єдиної системи управління пілотованими і безпілотнимі літальними апаратами не існує, відсутня також практика спільного бойового застосування пілотованої та безпілотної авіації. Управління частинами, підрозділами та екіпажами пілотованих та БпЛА здійснюється окремо відповідними системами управління, до складу яких входять органи управління (командири, штаби) та засоби управління. Для можливості сумісного управління пілотованими i БПЛА (ЗРГА) в авіації ПС ЗС України необхідне створення об'єднаної системи управління. Це мож- ливо досягти шляхом інтеграції систем управління та зв'язку БпАК в існуючу автоматизовану систему управління (АСУ) авіацією та ППО ЗС України та створенням узагальненого простору управління [22]. АСУ забезпечує автоматизацію найбільш складних і трудомістких задач управління авіацією та ППО (включаючи збір, обробку, збереження, документування та відображення оперативно-тактичної та радіолокаційної інформації про повітряну обстановку) за рахунок автоматизованого вирішення оперативно-тактичних задач (ОТЗ) у ході бойового чергування, підготовки та ведення бойових дій. Інтеграція може бути здійснена шляхом поширення функціональності АСУ щодо управління бойовими діями змішаних підрозділів за рахунок введення додаткових функцій спеціального програмного забезпечення (СПЗ) оперативно-тактичних задач, задач інформаційно-технічного спряження, технологічних задач $[11 ; 14 ; 22]$.

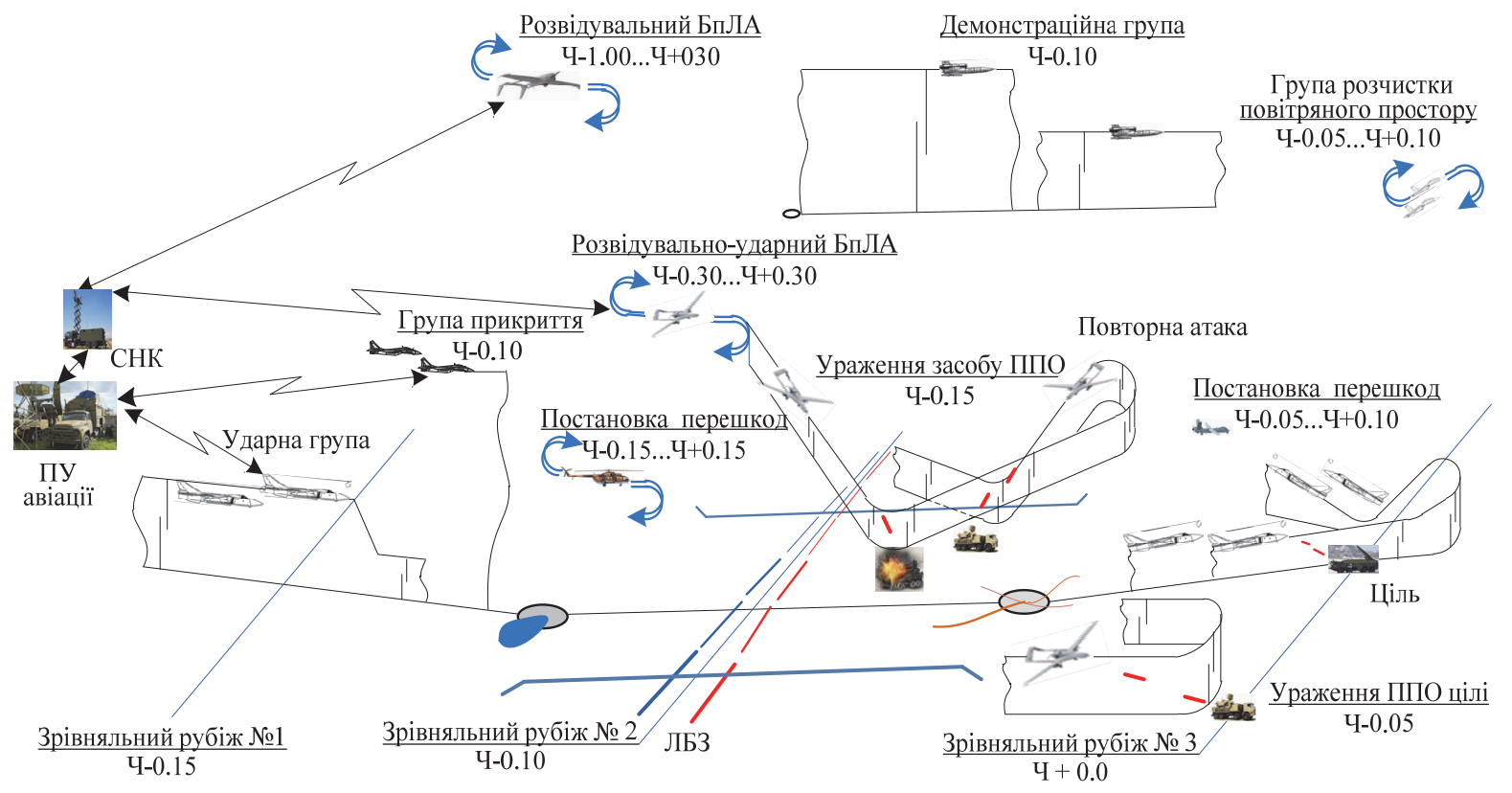

Рис. 4. Тактичні прийоми подолання ППО та нанесення удару змішаною різнорідною групою авіації (варіант)

Джерело: розроблено авторами.

Основним способом управління БпАК з АСУ авіації $є$ автоматизоване управління 3 використанням цифрових каналів зв'язку. При відсутності цифрових каналів зв'язку між АСУ авіації та БпАК, або неможливістю передачі (прийому) даних однією із сторін (АСУ або БПАК), управління може здійснюватися 3 використанням мовних каналів зв'язку.

Запропонована схема управління пілотованими і БпЛА при спільному виконанні бойових завдань 3 використанням об'єднаної системи управління, показана на рис. 5. 


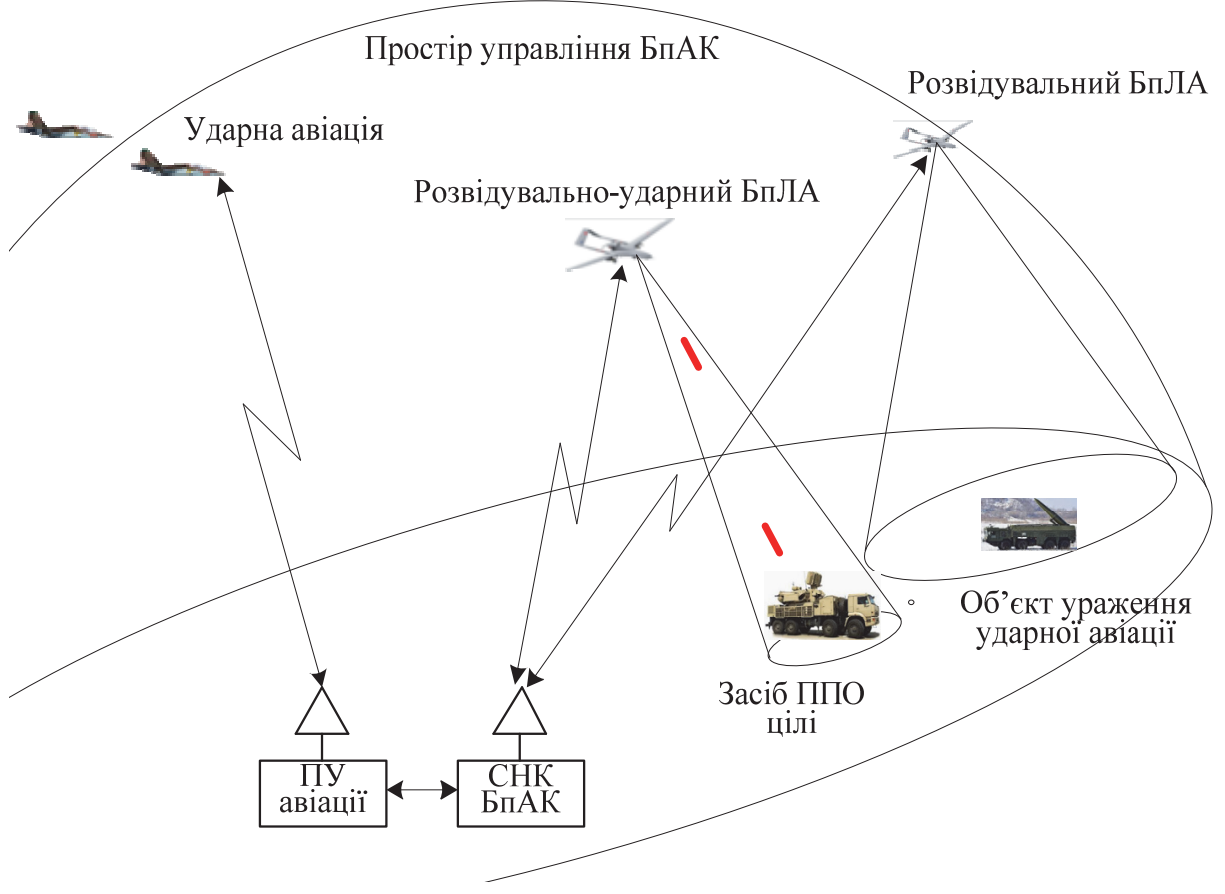

Рис. 5. Схема управління пілотованими і БпЛА при спільному виконанні бойових завдань 3 використанням об’єднаної системи управління (варіант)

Джерело: розроблено авторами.

Варіант виконання завдань ЗРГА у складі розвідувально-ударних та розвідувальних БпАК спільно $з$ пілотованою авіацією може бути наступний (рис. 6).

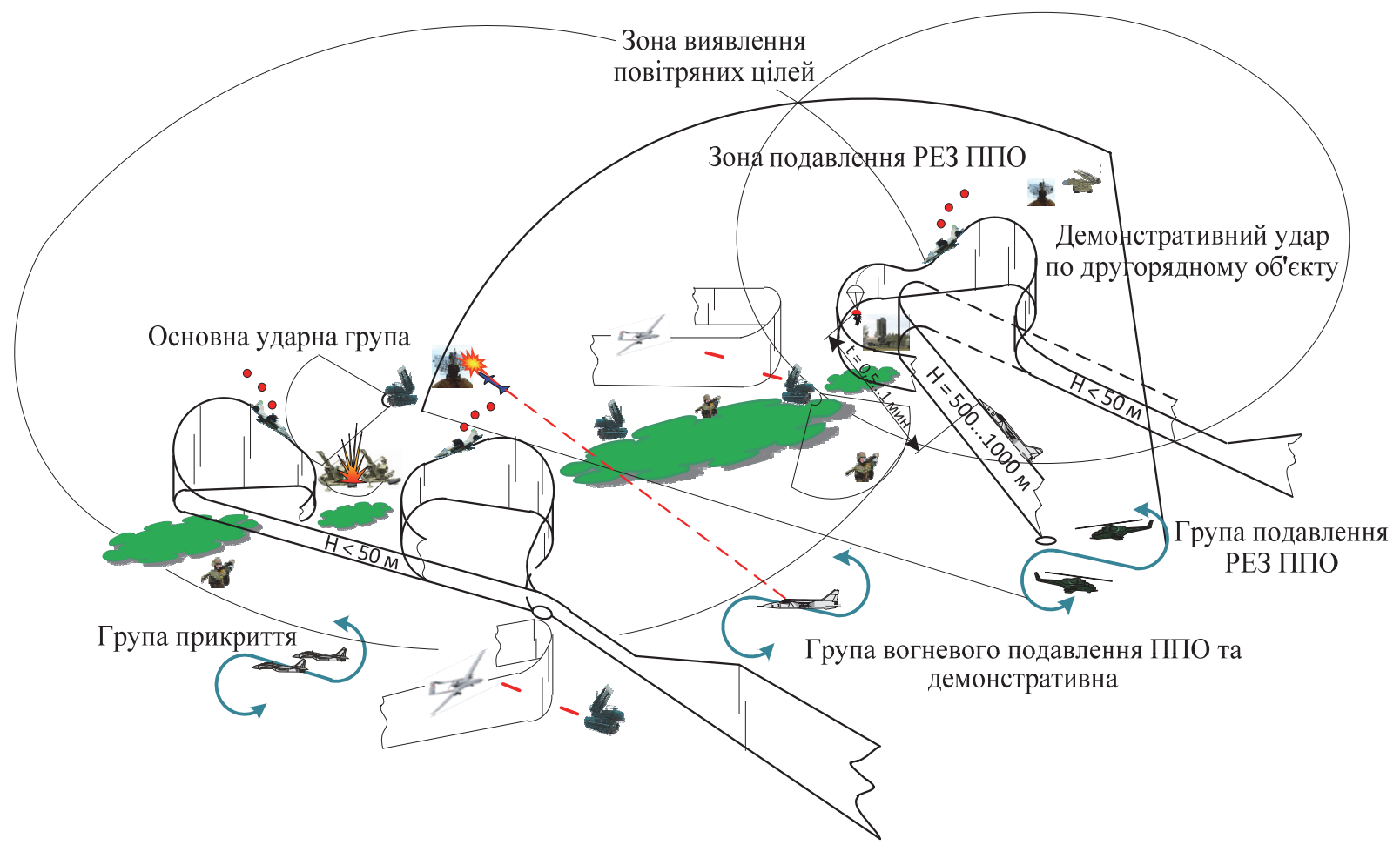

Рис. 6. Варіант виконання бойового завдання змішаною різнорідною групою авіації Джерело: розроблено авторами.

У встановлений час (згідно єдиного часового графіку) здійснюються послідовні запуски розвіду- вальних і розвідувально-ударних БпЛА та виведення їх за встановленими маршрутами на відповідних 
висотах в заданий район дій пілотованої авіації. Першими у заданий район виводяться розвідувальні БпЛА, які здійснюють пошук та ідентифікацію виявлених об'єктів. При виявленні засобів ППО, що мають потенційну загрозу пілотованої авіації, надається цілевказання розвідувально-ударним БпЛА для їх ураження. Моніторинг об'єктів та виявлення потенційно загрозливих цілей у заданому районі здійснюють також і розвідувально-ударні БпЛА. В разі виявлення цілей для ударної авіації надається цілевказання для їх ураження (або надсилається виклик на іiі виліт). При необхідності здійснюється ураження виявлених цілей розвідувально-ударними БпЛА $з$ метою припинення їх функціонування на визначений час. 3 положення чергування в повітрі силами ударної авіації удари наносяться негайно. При чергуванні на землі виконуються послідовні вильоти пар (ланок) літаків (ГТП) ударної авіації, політ за раціональними маршрутами і профілями у заданий район для нанесення авіаційних ударів по цілям, які були виявлені та уражені БпАК. Після нанесення ударів здійснюється контроль ураження цілей розвідувальними БпЛА.

\section{Висновки}

Таким чином, при розробці форм та способів спільного бойового застосування пілотованої і безпілотної авіації необхідні зміни у тактиці авіації.
Спільне застосування пілотованої та безпілотної авіації у ПС ЗС України на сьогодняшній день можливо у складі ЗРГА. В статті запропоновані доцільні форми бойового застосування та способи бойових дій, розподілення бойових завдань серед груп тактичного призначення ЗРГА, варіанти тактичних прийомів подолання ППО та нанесення ударів, напрям удосконалення існуючої системи управління авіації, який полягає в інтеграції системи управління і звязку БПАК в існуючу АСУ авіацією і ППО ЗС України із створенням єдиного інформаційного простору. Інтеграція може бути здійснена шляхом поширення функціональності АСУ щодо управління бойовими діями змішаних підрозділів за рахунок введення додаткових функцій СПЗ. Це може забезпечити автоматизацію задач управління авіацією та БПАК, включаючи збір, обробку, збереження, документування та відображення оперативно-тактичної та радіолокаційної інформації про повітряну обстановку, обмін інформацією між ПУ авіації та станцією наземного керування (СНК) БПАК у ході бойового чергування, підготовки та ведення бойових дій. Для цього потрібна високошвидкісна автоматизована мережа зв'язку з метою створення єдиного інформаційного простору, що має можливість здійснювати обмін інформацією з використанням стандартних протоколів повідомлень.

\section{Список літератури}

1. The Air Force Future Operating Concept (AFFOC). 2015. 48 p. URL: https://www.af.mil/Portals/1/ images/airpower/AFFOC.pdf (дата звернення: 24.06.2021).

2. United States Air Force Unmanned Aerial System Flight Plan 2009-2047. 2009. 37 p. URL: https://www.airforcemag.com/PDF/DocumentFile/Documents/2009/UAS-2047_briefing_Mathewson_072309.pdf (дата звернення: 24.06.2021).

3. Unmanned Systems Integrated Roadmap 2013-2038. 2012. 168 p. URL: https://www.hsdl.org/?view\&did=747559 (дата звернення: 24.06.2021).

4. Фещенко А. Л. Застосування БпЛА у військових конфліктах кінця XX - початку XXI ст. Військова історія. Київ : HУOУ, 2011. $20 \mathrm{c}$.

5. Концептуальные взгляды командования ВBC США на развитие беспилотной авиации. веб-сайт. URL: http://pentagonus.ru/publ/konceptualnye_vzgljady_komandovanija_vvs_ssha_na_razvitie_bespilotnoj_aviacii_2017/16-1-0-2776 (дата звернення: 24.06.2021).

6. Совместное применение пилотируемой и беспилотной авиации США в первой половине ХXI века. веб-сайт. URL: https://inlnk.ru/DBm3d (дата звернення: 24.06.2021).

7. Артюшин Л. М., Герасименко В. В. Метод формування спільної авіаційної групи. Сучасні інформаційні технології у сфері безпеки та оборони. 2021. № 1(40). С. 63-68.

8. Ананьев А. Н., Филатов С. В. Обоснование нового способа совместного применения авиации и беспилотных летательных аппаратов малой дальности в операциях. веб-сайт. URL: https://cyberleninka.ru/article/n/obosnovanie-novogosposoba-sovmestnogo-primeneniya-aviatsii-i-bespilotnyh-letatelnyh-apparatov-maloy-dalnosti-v-operatsiyah/viewer (дата звернення: 27.06.2021).

9. Ананьев А. Н., Филатов С. В., Рыбалко А. Г. Совместное применение пилотируемой авиации и разведывательноударных беспилотных летательных аппаратов малой дальности. веб-сайт. URL://cyberleninka.ru/article/n/sovmestnoeprimenenie-pilotiruemoy-aviatsii-i-razvedyvatelno-udarnyh-bespilotnyh-letatelnyh-apparatov-maloy-dalnosti/viewer (дата звернення: 27.06.2021).

10. Артеменко А. М., Астахов О. О., Коваль В. В., Жарик О. М. Погляди щодо подальшого розвитку форм і способів застосування Повітряних Сил Збройних Сил України в сучасних операціях (бойових діях). Наука $i$ техніка Повітряних Сил Збройних Сил Украӥни. 2015. № 2(19). С. 6-9.

11. Оганесян А. А. Применение интегрированной системы обмена информацией в комплексах с БпЛА. Перспективы развития и применения комплексов с беспилотными летательными аппаратами: сб. докладов и статей II науч.-прак. конф. Коломна : 924 ГЦ БпА МО РФ, 2017. С. 135-138. 
12. Шулежко В. В. Основні напрямки розвитку та застосування безпілотних літальних апаратів. Київ : МО України, 2013. 65 c.

13. Лялюк И. Н. Основные задачи автоматизации процессов применения беспилотных авиационных систем. Перспективы развития и применения комплексов с беспилотными летательными апаратами: сб. докладов и статей II науч.-прак. конф. Коломна : 924 ГЦ БпА МО РФ, 2017. С. 241-247.

14. Городнов В. П., Дробаха Г. А., Єрмошин М. А. Моделювання бойових дій військ (сил) протиповітряної оборони та інформаційне забезпечення процесів управління ними (теорія, практика, історія розвитку) : монографія Харків : ХВУ, 2004. 409 с.

15. Срмошин М. О., Федай В. М. Боротьба в повітрі. Харків : ХВУ, 2004. 381 с.

16. Котов О. Б., Лагузов О. І., Калмаканов С. А., Онипченко П. М. Тактика бомбардувальної авіації. Ч. І. Основи тактики підрозділів бомбардувальної авіації: навч. посіб. Харків : ХНУПС, 2018. 164 с.

17. Корнусь Ю. М., Онипченко П. М., Лагузов О. І. Тактика штурмової авіації. Харків : ХНУПС, 2020. 432 с.

18. Невзоров Р. В., Онипченко П. М., Корнусь Ю. М. Тактика винищувальної авіації : навч. посіб. Харків : ХНУПС, $2020.563 \mathrm{c}$.

19. Молоканов Г.Ф. Разработка тактического приема. Военная мысль. 2007. № 8. C. $42-48$ URL: http://militaryarticle.ru/voennaya-mysl/2007-vm/10052-razrabotka-takticheskogo-priema (дата звернення: 28.06.2021).

20. Ананьев А. Н., Рыбалко А. Г. Модель действий разведывательно-ударных групп БпЛА малого класса самолетного типа при поражении тактических истребителей ПВО на открытых стоянках аэродромных участков дорог. Воздущно-космические силы. Теория и практика. 2019. № 11. С. 58-68. URL: https://cyberleninka.ru/article/n/model-deystviyrazvedyvatelno-udarnyh-grupp-bespilotnyh-letatelnyh-apparatov-malogo-klassa-samoletnogo-tipa-pri-porazhenii/viewer (дата звернення: 29.06.2021).

21. Ананьев А. Н., Филатов С. В. Модель и алгоритм совместных действий смешанного авиационного полка и разведывательно-ударных групп БпЛА малого класса при поражении высокомобильных резервов противника. Воздушнокосмические силь. Теория и практика. 2019. № 10. C. 34-41. URL: https://cyberleninka.ru/article/n/model-i-algoritmsovmestnyh-deystviy-smeshannogo-aviatsionnogo-polka-i-razvedyvatelno-udarnyh-grupp-bespilotnyh-letatelnyh-apparatov/viewer (дата звернення: 30.06.2021).

22. Кірсанов С. О. Перспективи розвитку системи управління Збройних Сил України з використанням принципу єдиного інформаційного простору. Наука і техніка Повітряних Сил Збройних Сил Украӥни. 2010. № 1(3). С. 15-20.

\section{Вidомості про авторів:}

\section{Петров Василь Миколайович}

кандидат військових наук

старший науковий співробітник Харківського національного університету Повітряних Сил ім. І. Кожедуба,

Харків, Україна

https://orcid.org/0000-0003-4324-7540

\section{Шалигін Андрій Анатолійович}

кандидат технічних наук старший науковий співробітник начальник науково-дослідного відділу

Харківського національного університету

Повітряних Сил ім. І. Кожедуба,

Харків, Україна

https://orcid.org/0000-0002-1828-2443

\section{Кудрявцев Андрій Федорович}

науковий співробітник Харківського національного університету Повітряних Сил ім. І. Кожедуба, Харків, Україна

https://orcid.org/0000-0002-0319-6681

\section{Ситник Юрій Борисович}

кандидат технічних наук

завідувач кафедри Льотної академії

Національного авіаційного університету,

Кропивницький, Україна

https://orcid.org/0000-0003-0966-691X

\section{Марченко Олександр Михайлович}

науковий співробітник Харківського національного університету Повітряних Сил ім. І. Кожедуба,

Харків, Україна

https://orcid.org/0000-0002-4939-7833

\section{Information about the authors:}

\section{Vasyl Petrov}

Candidate of Military Sciences

Senior Research Associate of Ivan Kozhedub

Kharkiv National Air Force

University,

Kharkiv, Ukraine

https://orcid.org/0000-0003-4324-7540

\section{Andrii Shalyhin}

Candidate of Technical Sciences Senior Research

Head of Scientific Research Department

of Ivan Kozhedub Kharkiv

National Air Force University,

Kharkiv, Ukraine

https://orcid.org/0000-0002-1828-2443

\section{Andrii Kudriavtsev}

Research Associate of Ivan Kozhedub

Kharkiv National Air Force University,

Kharkiv, Ukraine

https://orcid.org/0000-0002-0319-6681

\section{Yuriy Sytnyk}

Candidate of Technical Sciences

Head of the Department of Flight Academy

of National Aviation University,

Kropyvnytzkyy, Ukraine

https://orcid.org/0000-0003-0966-691X

\section{Oleksandr Marchenko}

Research Associate of Ivan Kozhedub Kharkiv

National Air Force University,

Kharkiv, Ukraine

https://orcid.org/0000-0002-4939-7833 
Сурков Костянтин Юрійович

кандидат технічних наук

старший викладач Льотної академії

Національного авіаційного університету,

Кропивницький, Україна

https://orcid.org/0000-0003-3917-8335
Kostiantyn Surkov

Candidate of Technical Sciences

Senior Instructor of Flight Academy

of the National Aviation University,

Kropyvnytskyi, Ukraine

https://orcid.org/0000-0003-3917-8335

\title{
ФОРМЫ И СПОСОБЫ СОВМЕСТНОГО ПРИМЕНЕНИЯ ПИЛОТИРУЕМОЙ И БЕСПИЛОТНОЙ АВИАЦИИ ПРИ ВЕДЕНИИ БОЕВЫХ ДЕЙСТВИЙ
}

\author{
В.Н. Петров, А.А. Шалыгин, А.Ф. Кудрявцев, Ю.Б. Ситник, А.М. Марченко, К.Ю. Сурков
}

В статье рассмотрень основы тактики совместного применения пилотируемых и беспилотных летательных аппаратов при ведении боевых действий в составе смеманных разнородных групп авиации. К основнылм положениям тактики отнесены формы и способы боевого применения, боевые порядки и задачи авиации, тактические приемы их выполнения, функционирование системы управления. Соответственно для совместного применения смешанньх разнородных групп авиации предложены формы их боевого применения, обобщенный способ боевых действий, дано понятие смешанного боевого порядка, его количественно-качественного состава и параметров. Приведень частные задачи групп тактического назначения и летательных аппаратов смешанного боевого порядка, варианты тактических приемов преодоления системы противовоздушной обороны и нанесения ударов. Предложено направление усовершенствования существующей системы управления авиации для возможности совместного применения пилотируемых и беспилотных летательных аппаратов в разнородных группах, который заключается в интеграции системы управления и связи беспилотных авиационных комплексов в существуюшую автоматизированную систему управления авиацией и противовоздуиной обороной Вооруженных сил Украины с созданием единого информационного пространства.

Ключевые слова: ударная авиация, летательный аппарат, авиационный удар, боевой порядок, тактический прием.

\section{FORMS AND METHODS OF JOINT USE OF MANNED AND UNMANNED AVIATION WHEN CONDUCTING COMBAT OPERATIONS}

\section{Petrov, A. Shalyhin, A. Kudriavtsev, Yu. Sytnyk, O. Marchenko, K. Surkov}

The article discusses the fundamentals of tactics for the combined use of manned and unmanned aerial vehicles in the conduct of hostilities as part of mixed heterogeneous aviation groups. The main provisions of tactics include the forms and methods of combat use, combat formations and aviation tasks, tactical techniques for their implementation, and the functioning of the control system. Accordingly, for the joint use of mixed heterogeneous aviation groups, forms of their combat use, a generalized method of combat operations are proposed, the concept of a mixed combat order, its quantitative and qualitative composition and parameters is given. The particular tasks of tactical groups and aircraft that are part of a mixed combat formation, tactical techniques for overcoming the air defense system and delivering strikes are given. The direction of improvement of the existing aviation control system is proposed for the possibility of joint use of manned and unmanned aerial vehicles in heterogeneous groups, which consists in integrating the control and communication system of the BpAK into the existing ACS for aviation and air defense of the Ukrainian air defense system with the creation of a single information space. Integration can be achieved by way of expanding the functionality of the automated control system for controlling the combat actions of the change in production for the development of the additional functions of the SPZ. This can ensure the automation of aviation and BpAK control tasks, including the collection, processing, storage, documentation and display of operational-tactical and radar information about the air situation, the exchange of information between the aviation PU and the BPAK SNK during combat duty, preparation and conduct of hostilities. This requires a high-speed automated communication network in order to create a single information space, which has the ability to exchange information using standard message protocols.

Keywords: strike aircraft, aircraft, air strike, battle formation, tactical technique. 